\title{
DIE GESKIEDENIS VAN HOOF VAN STAF INLIGTING
}

\author{
Lt S.C. Le Grange*
}

\begin{abstract}
An efficient Defence Force Intelligence Service is of the utmost importance in the planning and successful execution of general and operational Defence Force policy.
\end{abstract}

The article hereunder discusses the early use of scouts by the Voortrekkers and proceeds to describe Information activities that existed during the First and Second World Wars. The eventual coming into existence of Chief of Staff Intelligence is finally dealt with.

\section{Inleiding}

Die bestaansreg, en in werklikheid die absolute noodsaaklikheid van ' $n$ inligtingsnetwerk in enige Verdedigingsorganisasie kan sonder veel insae deur enige denkende persoon begryp en na waarde geskat word. Enige organisasie, hetsy binne of buite ' $n$ Verdedigingsraamwerk vereis ' $n$ basiese inligtingsdiens wat rigting aan ' $n$ algemene breë beleid kan gee. 'n Doeltreffende weermagsinligtingsdiens is van deurslaggewende belang vir die beplanning en die suksesvolle deurvoer van algemene en operasionele weermagsbeleid. ${ }^{1}$

\section{Die vroeë gebruik van Verkenners}

Die Voortrekkerleiers het alreeds gebruik gemaak van verkenners wat vooraf verkenning moes doen ten einde korrekte optrede te kon bepaal. Plekname soos Spioenberg, Spioenkop, Spioenklip, Spioenbult illustreer die graad van belangrikheid wat die vroeë verkenningsaktiwiteite gehad het. 'n Onverskrokke verkenner en vegter in die persoon van Hans de Lange (Hans Dons) het voor en tydens die Groot Trek homself onderskei op die gebied van verkenningswerk.

Aan die einde van die $19^{e}$ eeu, met die konfliksituasie tussen Brittanje en Transvaal, het ' $n$ meer funksionele inligtingsnetwerk vir die eerste keer begin neig na ' $n$ meer georganiseerde insameling van feite. In 1980 het pres S.J.P. Kruger die reg gekry om agente aan te stel van wie hy nie nodig gehad het om verslag by die Volksraad te doen nie. Genl C.R. de Wet het self ook 'n aantal verkenners van sy eie gehad wat veel vrugte afgewerp het. ${ }^{2}$ Danie Theron en sy 'Wielrijders Rapportgangers Corps' wat hulle in 1900 by genl C.R. de Wet aangesluit het, het belangrike verkenningswerk gedoen gedurende die AngloBoereoorlog. Interessant ook, is die feit dat daar selfs 'n poging aan die kant van die Boerevroue gedurende die Anglo-Boereoorlog was om 'n bydrae te lewer op die gebied van die insameling van inligting. Die Kappie-kommando wat rondom mev. van Warmelo en haar dogter Hansie gesentreer het, het onder andere geheime oorlogsberigte ongesiens by die Engelse verby gesmokkel en Europa toe versend vir pres S.J.P. Kruger, wat op daardie stadium in Holland was.

\section{Die totstandkoming van die Unieverdedigingsmag en die inligtingsaktiwiteite gedurende die Eerste Wêreldoorlog}

Met die Verdedigingswet no 13 van 14 Junie 1912 het die UVM tot stand gekom. Die Verdedigingswet het egter hoegenaamd nie voorsiening gemaak vir 'n afsonderlike inligtingsdiens nie. Indien enige sodanige funksie wel op daardie stadium bestaan het, was dit nouliks identifiseerbaar in die algemene oorhoofse aktiwiteite van die Generale Staf afdeling. ${ }^{3}$

Die konflikarena wat deur die Eerste Wêreldoorlog veroorsaak is, het 'n ideale potensiële teelaarde vir inligtingsbedrywighede geskep. Ongelukkig was die omstandighede ook so dat die waarde van 'n inligtingsfunksie in daardie tyd uitsluitlik aan 'n fisiese konflik-situasie gekoppel is. Daar was nie werklik sprake van 'n inligtingstaffunksie in vredestyd nie.

Gedurende die oorlog van 1914 tot 1918 is daar gebruik gemaak van die Britse Inligtingsdiens. Die UVM self het egter ook ' $n$ bydrae gelewer in die vorm van Verkenners of 'Scouts' wat grootliks by die insameling van inligting betrokke was. 
Maj 'Langbaard' Grobler en 'n spesiale Verkenningskorps van 50 lede is byvoorbeald in Walvisbaai gestasioneer met die uitsluitlike opdrag om inligting vanaf Swakopmund en dieper die binneland in, in te samel. ${ }^{4}$ Maj P.J. Pretorius en sy Verkennerskorps was verantwoordelik vir die insameling van inligting in Duits-Oos-Afrika. ${ }^{5}$

Vanaf 1933 tot 1936 was die inligtingstaffunksie 'n bloot latente, vaagomlynde entiteit onder die Direkteur van Militere Opleiding en Operasies. Dieselfde afdeling, herbenoem as die Direkteur Operasies en Inligting onder kol P. de Waal, het in 1937 die Inligtingsaktiwiteite van die UVM omvat. Dit was egter ' $n$ blote verlengstuk van die afdeling met geen duidelik omlynde funksionele beleid nie. ${ }^{6}$

\section{Die Inligtingsopset gedurende die Tweede Wêreldoorlog}

In 1937, moontlik as gevolg van die dreigende oorlogswolke, word It-kol B.W. Thwaites deur die Hoof van die Generale Staf aangestel as Adjunkdirekteur van Militêre inligting op 'n deeltydse basis. Tydens ' $n$ vakansie in Brittanje het kol Thwaites by die Britse 'War Office' aangeklop ten einde informasie te verkry oor die daarstelling van 'n Militêre Inligtingsisteem. Die Britse 'War Office' was egter nie heeltemal geneë om inligting aan kol Thwaites te verskaf nie agv 'n gevoel van wantroue teenoor die Hertzog-regering. In September 1939 het kol Thwaites 'n verslag aan kol P. de Waal (Direkteur van Operasies en Inligting) voorgelê. Kol Thwaites het in die verslag die absolute ondoeltreffendheid van die Inligtingsorganisasie blootgelê en sy kommer daaroor uitgespreek. Hy het tereg na die Inligtingsafdeling verwys as die senuweestelsel van die Verdedigingsmag waarsonder doeltreffende optrede deur die Verdedigingsmag ernstig gekniehalter word. Informasie sou uitsluitlik op ' $n$ vrywillige basis bekom moes word agv 'n ernstige tekort aan fondse. In September 1939 kom 'n Inligtingsafdeling totstand wat met ' $n$ klein groepie Aktiewe Burgermaglede moes funksioneer. Vrywillige korrespondente het informasie verskaf van oral oor die Unie en veral die inligting van Suidwes af, waar daar destyds rekening gehou moes word met die infiltrasie van die Nazi-party, was van kardinale belang Daar was egter geen manier om die egtheid en betroubaarheid van die informasie te verifieër nie. 'n Vrywillige agent is in Nairobi verkry en bande is gesluit in Noord-Rhodesië, Nyassaland, Tanganjika en Kenia
In 1940 is kol Thwaites aangesê om 'n Suid-Afrikaanse Korps van Inligting daar te stel. Hy moes ook voorsiening maak vir sekuriteitspersoneel. ${ }^{7}$

\section{Die totstandkoming van 'n Hoof van Staf Inligting}

$\mathrm{Na}$ deelname aan die Tweede Wêreldoorlog het die Unie nog steeds oor geen spesifieke inligtingsorganisasie beskik nie. Die Unie was hoofsaaklik (soos trouens alle Statebondslande op daardie tydstip) op die Britse 'War Office' aangewys vir sy inligtingsbehoeftes. Die Inligtingstaf op daardie tydstip het bestaan uit enkele offisiere op die staf van die Hoof van die Generale Staf (HGS). Alle inligting was hoofsaaklik gerig op gevegsinliging, gebaseer op die Britse patroon tydens die Tweede Wêreldoorlog.

Na die Republiekwording in Mei 1961 was SuidAfrika op homself aangewys vir die verkryging van inligting. Om aan hierdie behoefte te voorsien is die Direkteur Militere Inligting (DMI) geskep. Op daardie stadium was die organisasie van DMl geweldig omvattend en het onder andere nasionale strategiese inligting ingesluit. Verskeie offisiere het inligtingskursusse oorsee bygewoon - hoofsaaklik in Engeland, Duitsland, Frankryk en die VSA. Gedurende 1964 het die $\mathrm{DMI}$ onafhanklike status verkry en is direk onder die Kommandant-Generaal, SAW ingeskakel. In 1965 is die Direkteur Militêre Inligting onder die Hoof van Verdedigingstaf ingevoeg, maar in 1967 is DMI weer direk onder die destydse KG, SAW ingeskakel. In September 1968 het 'n nuwe organisasie, (later genoem die Buro vir Staatsveiligheid) die DMI geabsorbeer. Die teeninligtingsaspek het onder die Direkteur Teeninligting (DTI) by die Suid-Afrikaanse Weermag gebly. DTI was aanvanklik na die Adjunk-Operasies (HVS) oorgeplaas maar is Februarie 1969 na die Adjunk Administrasie (HVS) oorgeplaas. In April 1969 is DMI weer gestig. Die formele kennisgewing van die Buro vir Staatsveiligheid (BSV) in 1969 het onsekerheid ten opsigte van die voortbestaan van DMI laat ontstaan. Die Potgieterkommissie het September 1969 ondersoek ingestel na die behoorlike funksionering en koördinering van die staatsdepartemente wat met veiligheid gemoeid is.

Die resultaat van die Potgieterverslag was die Wet op Veiligheidsinligting en die Staatsveiligheidsraad van 1972. Hierdie Wet bepaal grootliks die inligtingsverantwoordelikheid van 
die departemente. Die direktorate DMI en DTI is in Junie 1971 organisatories bymekaargevoeg as ' $n$ komponent van die Verdedigingstaf. In 1972 is die Afdeling Militêre Inligting (AMI) gestig, direk verantwoordelik aan die destydse Kommandant-generaal, SAW.

In 1974 is die Stafstruktuur gereorganiseer op die grondslag van die afsonderlike staffunksies van personeelbestuur, inligting, operasies en logistiek. Die Hoof van Staf Inligting het ' $n$ spesialis- stafafdeling geword met ' $n$ hoof van staf direk verantwoordelik aan die Hoof van die Suid-Afrikaanse Weermag.

Die funksionele verantwoordelikheid van $A M I$ is om 'n militêre inligting- en teeninligtingsdiens aan die SAW te lewer. ${ }^{8}$

* Lt S.C. Le Grange, BA HOD is verbonde aan die Militêre Informasieburo van die SAW.

\section{Venwysings}

1. SAW Argief, Argiefgroep HWA, Houer 156, Leêr 114/7/2.

2. SESA, Vol 4, p. 387

3. SAW Argief, Pamflet, Houer 99 (History of the Defence Force), p. 1

4. SAW Argief, Argiefgroep DCG, Houer 719, Leêr 1213/9199: Formation of Grobler's Scouts, Brief van die Sekretaris van Verdediging aan kol Skinner.

5. SAW Argief, Argiefgroep DGS, Houer 447, Leêr 744/59: Suggested formation of a Scout Unit

6. SAW Argief, Argiefgroep CGS, Leêr $51 / 5$ Vol 1: Duties General Staff and other Duties.

7. Narratives and Unfo, 24, 25.

8. SAW Argief.

\section{Bronnelys}

BOEKE:

Narratives and Unfo: 24, 25

Sesa Vol. 4

\section{SAW ARGIEF:}

Argietgroep HWA, Houer 156, Leêr 114/7/2

Argiefgroep DCG, Houer 719, Leêr 1213/9199: Formation of Grobler's Scouts.

Argiefgroep CGS, Houer 447, Leêr 744/59: Suggested formation of a Scout Unit.

Argiefgroep CGS, Houer 49, Leêr 51/5 Vol. 1: Duties of the General Staff and other Duties. 